Available online at GSC Online Press Directory

GSC Biological and Pharmaceutical Sciences

e-ISSN: 2581-3250, CODEN (USA): GBPSC2

Journal homepage: https://www.gsconlinepress.com/journals/gscbps

(RESEARCH ARTICLE)

\title{
Influence of using different percentages decomposed rice straw as alternative substrate on celery plants
}

\author{
Sadek Ihab Ibrahim *, Moursy Fatma Sayed and Ahmed Mohamed Said Mohamed \\ Central Laboratory for Agricultural Climate (CLAC), Agricultural Research Center (ARC), Giza, Egypt.
}

Publication history: Received on 12 December 2019; revised on 20 December 2019; accepted on 23 December 2019

Article DOI: https://doi.org/10.30574/gscbps.2019.9.3.0237

\begin{abstract}
This paper focused on evaluating the effect of using different decomposed percentages of rice straw as alternative substrate on growth, yield and irrigation water use efficiency (IWUE) of celery plants. The experimental layout was in the experimental farm of Central Laboratory for Agricultural Climate and the design was randomized complete block with three replications. Celery seedlings (cv. Green giant) were transplanted in 1st of December, 2017/2018 and 2018/2019. Four ages (levels of decomposed) of rice straw were used (new rice straw, old rice straw 3 months, old rice straw 6 months and old rice straw 9 months) as a substrate in this investigation compared to clay soil. Results indicated that using the old rice straw, 6 months substrate recorded a moderate substrate temperature. Plant length, N, P, soluble sugar content and yield were not affected by cultivated celery plants in clay soil or old rice straw 6 months as substrate. whereas, plant diameter, chlorophyll reading, $\mathrm{K}$ and vitamin $\mathrm{C}$ content were affected negatively by using different percentages decomposed rice straw as alternative grown substrate. On the other hand, irrigation water use efficiency (IWUE) enhanced by cultivated celery plants in clay soil and old rice straw 6 months substrate.
\end{abstract}

Keywords: Celery; Rice Straw; Decomposed; Irrigation water use efficiency (IWUE).

\section{Introduction}

Rice is one of the major foods, with consumption per capita of $65 \mathrm{~kg}$ per year, accounting for $20 \%$ of global ingested calories. Rice production is expected to increase significantly in the near future to feed the rising human population. Today, paddy rice culture produces 660 million tons of rice, along with 800 million dry tons of agricultural residues [1], mainly straw, a fact which makes rice straw one of the most abundant agricultural residues by products available in large quantities.

Only $20 \%$ of the annual production is used for purposes, such as ethanol and paper production [2], and the remaining, $80 \%$ is left on the field or burning, which contributes in global warming and atmospheric pollution [3].

Rice straw is a lingo-cellulosic material consisting predominantly of celluloses and hemi-celluloses (more than 60 percent) in addition to lignin's (15 to 20 percent), water-soluble substances (5 to 12 percent), mineral matter or ash and proteins which are usually present in very small amounts (2.2 to 3.0 percent), [4]. In addition, rice straw contain high nutrient value from (nitrogen, phosphorus, sulfur and potassium), which can use as a source for very high nutrient value as well as supplies organic matter for $\mathrm{N}$ fixation by heterotrophic $\mathrm{N}$-fixing microorganisms, which could be absorbed by succeeding crop [5], [6].

In Egypt, rice crop is consider the most important field crop, Egypt produce about 4.5 million tons of rice. Nowadays, there is a public awareness of burning agricultural residues, procedures leads to unacceptable air quality. This is partly

\footnotetext{
${ }^{*}$ Corresponding author

E-mail address: dr.ihabsadek@yahoo.com
}

Copyright (C) 2019 Author(s) retain the copyright of this article. This article is published under the terms of the Creative Commons Attribution Liscense 4.0 
brought about by recent reports on what is locally known as "the Black Cloud" in the environmental ecosystem. Probably the most prominent example of this is rice straw, of which in recent years nearly 3.7 million tons per year was burned in the field, creating both an economic waste and environmental problems [6].

The burning of crop residues in fields is one of the most significant activities of global biomass burning [7], and contributes substantially to air pollution. After harvesting, the rice straw waste is frequently burned in the open in regions with insufficient time before planting the next crop to remove and dispose of it in a more controlled manner, such as in a furnace or by using another closed burning technique [8]. In addition, some farmers believe that rice straw open burning can remove weeds, control diseases, and release nutrients for the next crop [9]. However, in contrast to closed burning, the open burning of rice straw is an uncontrolled combustion process in which the products of burning are emitted into the atmosphere, such as $\mathrm{CO}_{2}, \mathrm{CO}, \mathrm{CH}_{4}$, particulate matter (PM), $\mathrm{NOx}$, and $\mathrm{SO}_{2}$, influencing both the local air quality and global climate [10], [11], [12], [13]. Furthermore, burning rice straw in fields may contribute to the emission of harmful air pollutants, such as Polycyclic Aromatic Hydrocarbons (PAHs), Poly Chlorinated Dibenzo Dioxins (PCDDs), and Poly Chlorinated Dibenzo Furans (PCDFs), threatening human health [14], [15], [16], [17].

On the other hand, growing media have three main functions: 1) providing aeration and water, 2) allowing for maximum root growth and 3) physically support the plant. Growing media should have large particles with adequate pore spaces between the particles [18].

Moreover, cultivated vegetable crops on compacted rice straw bales such as straw berry, pepper, tomato, cucumber and okra in open field or under greenhouse were promised method to utilize rice straw residues [19], [20]. In addition, the cultivation on compacted rice straw bales was used in the soil, which suffered from soil borne diseases and high salinity. The dynamic of decomposed rice straw characteristics throw the time and found that the mass, $\mathrm{C} / \mathrm{N} \mathrm{ratio}, \mathrm{N}, \mathrm{P}$ and $\mathrm{K}$ released for decomposed rice straw are changed dramatically throw the time in the short period [21].

Celery (Apium graveolens L.) is popular vegetable and aromatic plant grown mostly for its fresh herbs as salad crop in different parts of the world. Celery thrives best in climates with a long, cool growing season, especially at night. Optimum production occurs when mean temperatures range between $16{ }^{\circ} \mathrm{C}$ and $21{ }^{\circ} \mathrm{C}$ with the introduction of cultivars for tolerating upper temperature ranges. Celery can be produced in tunnel houses for early or late markets [22].

This study aims to investigate the effect of using different percentages decomposed rice straw as alternative grown substrate on celery plants growth quality and yield.

\section{Material and methods}

\subsection{Experimental site}

For evaluating superiority of rice straw different decomposition ages as a cultivation substrate for growing celery under greenhouse conditions, the current investigation was held on at research farm of the Central Laboratory for Agricultural Climate (CLAC), Agricultural Research Center (ARC), Ministry of Agriculture and Land Reclamation during seasons of $2017 / 2018$ and $2018 / 2019$. The geographical coordinate of the experimental site is $30^{\circ} .00^{\prime} .00^{\prime \prime} \mathrm{N}$ and $31^{\circ} .140^{\prime} .00$ " E.

\subsection{Greenhouse preparation}

The experiment was conducted under single tunnel greenhouse, $60 \mathrm{~m}$ long, $9 \mathrm{~m}$ width and $3.25 \mathrm{~m}$ height. The greenhouse was covered by white screen net. The total area of greenhouse was $540 \mathrm{~m}^{2}$. It was divided into five ridge beds separated by pathway $0.60 \mathrm{~m}$ wide. Each ridge bed was $1 \mathrm{~m}$ width and $60 \mathrm{~m}$ long.

\subsection{Plant material and culture circumstances}

Celery seedlings (cv. Green giant) were transplanted to the used pots in $1^{\text {st }}$ of December of $2017 / 2018$ and 2018/2019 seasons. The spacing between plants inside the same raw was $0.5 \mathrm{~m}$ and the spacing between rows was $0.60 \mathrm{~m}$. Twenty litters volume`s pots were used in this experiment as a cultivation containers. The pots were filled with both transferred soil and different ages of chopped rice straw media. In addition, a basic mix of compost and nutrients such as N, P, K and $S$ (recommended doses) were applied under the last five centimeters of pots height and compacted by hand. The characteristics of the rice straw are shown in Table (1). All rice straw media were wetted by spraying water daily for one week before cultivation to keep the rice straw media at a proper moist. Used pots were irrigated using drip irrigation system in which the dripping line was placed above the pots about $5 \mathrm{~cm}$ from the center of the transplants. 
Table 1 Characteristics of rice straw media

\begin{tabular}{ll}
\hline Characteristics & Value \\
\hline Moisture content (\%) & 8.90 \\
EC (dS/m) & 3.5 \\
$\mathrm{pH}$ & 6.55 \\
Organic matter (\%) & 80.25 \\
Organic carbon (\%) & 77.56 \\
Total N (\%) & 0.76 \\
Total P (\%) & 0.63 \\
Total K (\%) & 0.42 \\
Ash (\%) & 12.3 \\
Chemical available (mg / kg) & \\
N & 896 \\
P & 474 \\
K & 465 \\
C / N ratio & $66: 1$ \\
\hline
\end{tabular}

\subsection{Treatments}

Four ages (levels of decomposed) of rice straw were used as a substrate in this investigation compared to the soil as follow:

New rice straw (from the field). It was shredded to 2-4 inches using a grinder machine.

Three months rice straw (cultivated three months before).

Six months rice straw (cultivated six months before).

Nine months rice straw (cultivated nine months before).

Soil as a control.

The used soil was classified as sandy clay loam (Table 2).

Table 2 Characteristics of the soil used as control

\begin{tabular}{|c|c|c|c|c|c|c|c|c|}
\hline \multicolumn{2}{|c|}{$\begin{array}{l}\text { Particle } \\
\text { distribution }\end{array}$} & \multirow{2}{*}{$\begin{array}{l}\text { size } \\
\text { clay }\end{array}$} & \multirow[t]{2}{*}{ Texture } & \multirow[t]{2}{*}{$\mathbf{p H}$} & \multirow[t]{2}{*}{$\mathrm{EC} \mathrm{dS} / \mathrm{m}$} & \multirow[t]{2}{*}{$\mathrm{CaCo}_{3}(\%)$} & \multirow[t]{2}{*}{$\begin{array}{l}\text { Organic } \\
(\%)\end{array}$} & \multirow[t]{2}{*}{ matter } \\
\hline Sand & Silt & & & & & & & \\
\hline 57.3 & 16.7 & 26 & Sandy clay loam & 8.2 & 2.4 & 16.0 & 0.35 & \\
\hline \multicolumn{9}{|c|}{ Soluble cations and anions (meq/l) } \\
\hline $\mathrm{Ca}^{+}$ & $\mathrm{Mg}^{++}$ & $\mathrm{Na}^{+}$ & $\mathrm{K}^{+}$ & $\mathrm{Cl}^{-}$ & $\mathrm{HCO}_{3}^{-}$ & & & \\
\hline 6.0 & 3.0 & 20.1 & 1.2 & 13.0 & 2.6 & & & \\
\hline
\end{tabular}




\subsection{Climatic measurements}

In order to determine the climatic profile during the growing seasons, average soil temperature were manually recorded every day with occasionally exception. As well as, all temperature of all tested substrates were daily recorded at $10 \mathrm{~cm}$ depth in each treatment and in soil (control), it was recorded by using a digital thermo/hygrometer Art. No.30.5000/30.5002 (Produced by TFA, Germany). The obtained temperature values were averaged in order to create the temperature profile for each of the two growing seasons.

\subsection{Recorded data}

Data were recorded at the end of the growing seasons (after 90 days from transplanting) on plant length (cm), plant diameter (cm), chlorophyll (SPADE), soluble sugar (by the anthrone method, [23], vitamin C (by using the 2, 6 Dichlorophenol indophenol method described in Association of Official Analytical Chemists [24], nitrogen, potassium and phosphorus content in plants (\%), (according to distillation in a Macro-Kjeldahle apparatus [25] and atomic absorption spectrophotometric [26] methods), and total yields as well as, average fruit weight were determinate.

\subsection{Calculation of irrigation requirements}

Irrigation requirements for celery plants was calculated based on crop evapotranspiration (ETo) and the evapotranspiration under net-covered greenhouse conditions was estimated according to [27]. As follow:

$\mathrm{ET}_{\mathrm{GH}}=0.7 \times$ ETo outside

Where:

$\mathrm{ET}_{\mathrm{GH}}=$ the evapotranspiration under greenhouse conditions

ETo outside $=$ the evapotranspiration in the open field conditions

Drip irrigation system was used for irrigation which applied following the evapotranspiration (ETc) method according to soil water balance [28] as follows:

$\mathrm{ETc}=\mathrm{ET}_{\mathrm{GH}} \mathrm{x} \mathrm{Kc}$

Where:

ETc $=$ the water requirements for celery plant under greenhouse conditions

$\mathrm{ET}_{\mathrm{GH}}=$ the evapotranspiration under greenhouse conditions

$\mathrm{Kc}=$ the crop coefficient for celery plant

The Kc of celery plants was used according to [29], the Kc values were varied throughout different plant growth stages and increased from 0.7 (initial stage) to 1.05 (middle stage) from transplanting to the begging of harvest, and decreased again from 1.05 to 0.95 at the end of the growing season. The irrigation requirements for celery plants was calculated according to [29]. Drip irrigation was used from December $1^{\text {st }}$ up to the end of the growing season in $30^{\text {th }}$ of March. The total amount of irrigation water was estimated by water gauger and Table (3) shows the total amount of irrigation water for greenhouse area during both growing seasons.

Table 3 Irrigation water consumption amount for celery plants in both growing seasons

\begin{tabular}{lll}
\hline & \multicolumn{2}{l}{ L /plot / Month } \\
\cline { 2 - 3 } Period & $2017-2018$ & 2018- 2019 \\
\hline (1-31 Dec.) & 557.500 & 557.500 \\
(1-31 Jan.) & 1346.600 & 1346.600 \\
(1-28 Feb.) & 3009.800 & 3009.800 \\
(1-30 Mar.) & 4809.400 & 4809.400 \\
Total consumption (L / plot) & 9723.300 & 9723.300 \\
Total consumption (L / GH) & 48616.500 & 48616.500 \\
Total consumption (M3 / GH) & 48.617 & 48.617 \\
\hline
\end{tabular}




\subsection{Irrigation Water use efficiency (IWUE)}

Irrigation Water use efficiency was calculated for fresh yield of celery plant for different treatments according to [30], using the following equation

IWUE = Total yield $(\mathrm{Kg}) /$ Total water consumption $\left(\mathrm{m}^{3}\right)$.

\subsection{Experimental design and data analysis}

The experimental design was arranged in randomized complete block design with three replications.

The results obtained in each study variable were submitted to analysis of variance and Duncan's multiple range test $(\mathrm{P} \leq 0.05)$ for comparison of means, through STATISTICA version7 [31].

\section{Results}

\subsection{Average rice straw substrate and soil temperature}

Average substrate and soil temperature during 2017/2018 and 2018/2019 seasons was shown in Figure (1).

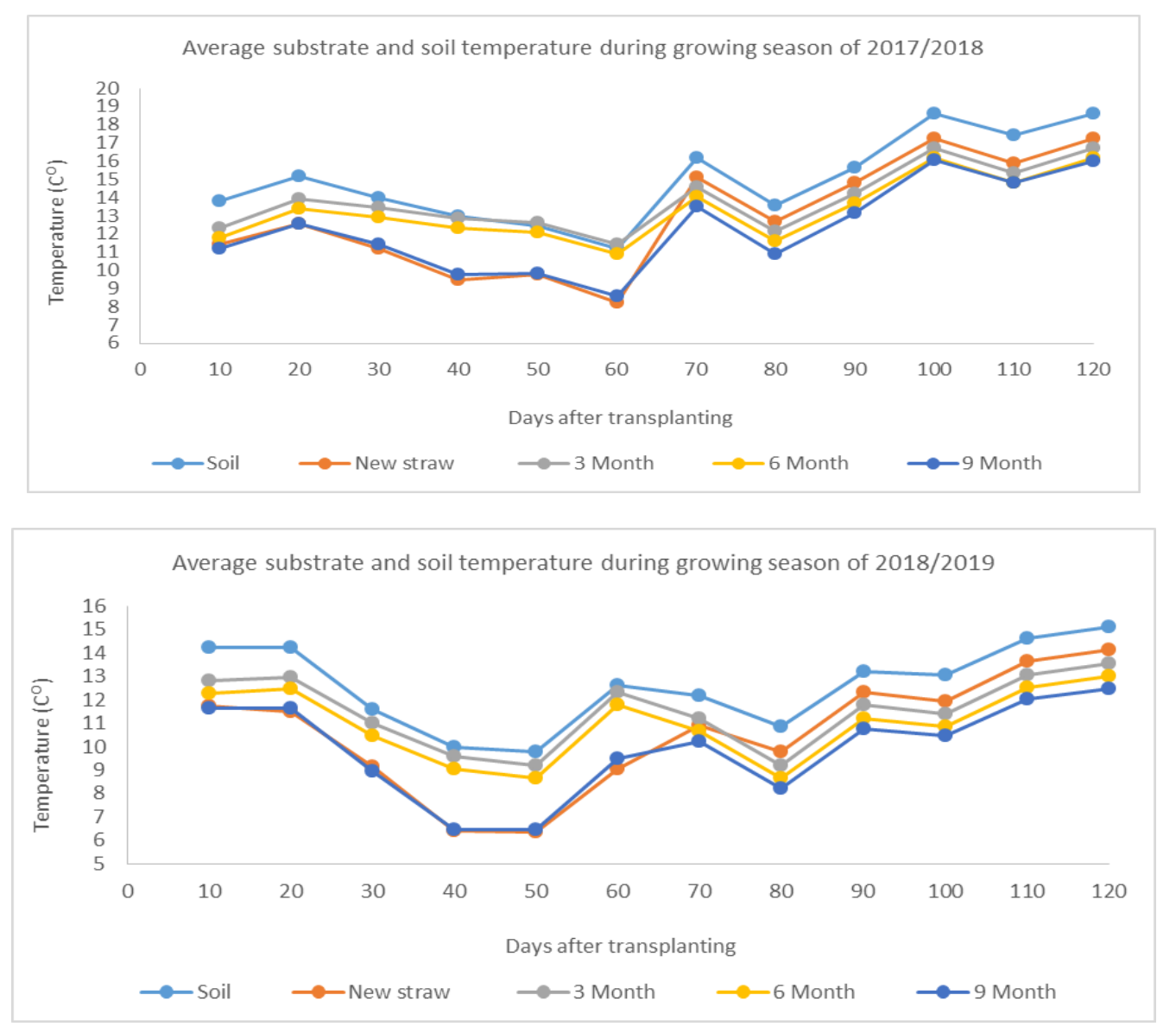

Figure 1 Average substrate and soil temperature during two growing seasons 2017/2018 and 2018/2019.

The illustrated data indicated that the control treatment (clay soil) had the highest value of the average soil temperature during the two tested seasons. Whereas, the new rice straw substrate was ranked the second and the old rice straw, 3 months substrate was the third highest temperature, (from the day eighty after transplanting to the end of the growing season). Focusing on the lowest substrate temperature, it was notable that both of the old rice straw substrate, 9 months and the new rice straw substrate were the lowest (semi similar values) starting from transplanting date until the day sixty. However, the second highest value was recorded in old rice straw 3 months substrate starting from the transplanting date until the day seventy. Generally, during the season period, the old rice straw substrate, 9 months was absolutely the lowest, and the 6 months rice straw substrate occupy the second lowest position. While, old rice straw 3 
months substrate recorded a moderate of average substrate from the beginning to the end of growing season in both tested seasons.

Illustrated data in Table (4) showed effect of using different percentages decomposed of grown substrate on plant length, plant diameter and chlorophyll in celery plants, compared with clay soil.

\subsection{Plant length}

Data in Table (4) indicated that plant length was affected significantly by using different decomposition percentages of rice straw as a substrate. The greats values of plant length was obtained with clay soil treatment followed by old rice straw 6 months without any significant different between them. While, the lowest values of this parameter was recorded by new rice straw treatment. The same trend was observed in both growing seasons.

Table 4 Effect of using different percentages decomposed of rice straw substrate on plant length $(\mathrm{cm})$, plant diameter (cm) and chlorophyll reading during 2017/2018 and 2018/2019 seasons.

\begin{tabular}{llll}
\hline Treatments & Plant length & Plant diameter & chlorophyll \\
\cline { 2 - 4 } & First season & & \\
\cline { 2 - 4 } New rice straw & $28.0 \mathrm{D}$ & $3.2 \mathrm{D}$ & $1.089 \mathrm{E}$ \\
Old rice straw 3 months & $35.2 \mathrm{~B}$ & $4.4 \mathrm{C}$ & $1.233 \mathrm{C}$ \\
Old rice straw 6 months & $38.3 \mathrm{~A}$ & $5.0 \mathrm{~B}$ & $1.475 \mathrm{~B}$ \\
Old rice straw 9 months & $31.4 \mathrm{C}$ & $3.9 \mathrm{C}$ & $1.138 \mathrm{D}$ \\
Clay soil (Control) & $38.8 \mathrm{~A}$ & $5.7 \mathrm{~A}$ & $1.503 \mathrm{~A}$ \\
\hline & Second season & & \\
\hline New rice straw & $27.4 \mathrm{D}$ & $3.1 \mathrm{C}$ & $1.088 \mathrm{E}$ \\
Old rice straw 3 months & $34.0 \mathrm{~B}$ & $4.2 \mathrm{~B}$ & $1.232 \mathrm{C}$ \\
Old rice straw 6 months & $37.2 \mathrm{~A}$ & $4.9 \mathrm{~A}$ & $1.473 \mathrm{~B}$ \\
Old rice straw 9 months & $30.6 \mathrm{C}$ & $3.7 \mathrm{~B}$ & $1.137 \mathrm{D}$ \\
Clay soil (Control) & 37.8 A & 5.4 A & $1.502 \mathrm{~A}$ \\
\hline
\end{tabular}

\subsection{Plant diameter}

Presented data in Table (4) showed that, plants which cultivated in the clay soil and the old rice straw, 6 months treatments gave the highest values of plant diameter. Whereas, cultivated celery plants in new rice straw was obtained the lowest values of this parameter. The same results were observed in the second season. Moreover, in the second season, noticed that there is no significant difference between the old rice straw, 3 months and 9 months decomposed period treatments.

\subsection{Chlorophyll}

Chlorophyll reading was affected significantly by using rice straw as a growing substrate. In Table (4) we found that using rice straw as a substrate lead to decreased chlorophyll reading at celery leaves. The highest chlorophyll reading was recorded in the plants which cultivated in clay soil followed by the old rice straw, 6 months treatment, respectively. Whereas, new rice straw treatment gave the lowest chlorophyll reading. This result was true at two tested seasons.

\subsection{Nitrogen, phosphorus and potassium content in leaves}

Data in Table (5) revealed the significant effect of different decomposed percentages of rice straw on celery leaves content of (N, P and K). The greatest leaves content of N, P and K were noticed at the clay soil and the old rice straw, 6 months treatments without any significant difference between them, except $\mathrm{K}$ content which gave a significant difference between the clay soil and other tested treatments. This trend was true in both growing seasons. 
Table 5 Effect of using different percentages decomposed of rice straw substrate on celery leaves content of (N, P and K \%) during 2017/2018 and 2018/2019 seasons.

\begin{tabular}{|c|c|c|c|}
\hline Treatments & $\mathbf{N}$ & $\mathbf{P}$ & $\mathbf{K}$ \\
\hline & \multicolumn{3}{|c|}{ First season } \\
\hline New rice straw & $39.138 \mathrm{C}$ & $4.658 \mathrm{D}$ & $35.596 \mathrm{D}$ \\
\hline Old rice straw 3 months & $43.187 \mathrm{~B}$ & $8.518 \mathrm{~B}$ & $43.019 \mathrm{C}$ \\
\hline Old rice straw 6 months & $51.791 \mathrm{~A}$ & $9.917 \mathrm{~A}$ & $48.856 \mathrm{~B}$ \\
\hline Old rice straw 9 months & $41.905 \mathrm{~B}$ & $5.764 \mathrm{C}$ & $41.197 \mathrm{C}$ \\
\hline \multirow[t]{2}{*}{ Clay soil (Control) } & $53.545 \mathrm{~A}$ & $10.530 \mathrm{~A}$ & $55.975 \mathrm{~A}$ \\
\hline & \multicolumn{3}{|c|}{ Second season } \\
\hline New rice straw & $38.667 \mathrm{C}$ & $4.607 \mathrm{D}$ & $35.167 \mathrm{D}$ \\
\hline Old rice straw 3 months & $42.667 \mathrm{~B}$ & $8.423 \mathrm{~B}$ & $42.500 \mathrm{C}$ \\
\hline Old rice straw 6 months & $51.167 \mathrm{~A}$ & $9.807 \mathrm{~A}$ & $48.267 \mathrm{~B}$ \\
\hline Old rice straw 9 months & $41.400 \mathrm{~B}$ & $5.700 \mathrm{C}$ & $40.700 \mathrm{C}$ \\
\hline Clay soil (Control) & $52.900 \mathrm{~A}$ & $10.413 \mathrm{~A}$ & $55.300 \mathrm{~A}$ \\
\hline
\end{tabular}

\subsection{Soluble sugar}

Recorded data in Table (6) show the effect of different decomposed percentages of rice straw substrate and the clay soil on celery plants content of soluble sugar. The celery plants which cultivated in both the clay soil and the old rice straw, 6 months treatments were obtained the greatest content of soluble sugar, without any significant difference between them. However, plants grown in the new rice straw was indicated lowest content of soluble sugar. This result was indicated in the second season.

\subsection{Vitamin C}

Data in Table (6) obtained that cultivation in clay soil treatment increased the content of vitamin C in celery plants followed by the old rice straw, 6 months treatment which replaced second place. Moreover, using new rice straw as a substrate decreased vitamin $\mathrm{C}$ content in plants. Generally, using rice straw as a substrate led to reduce content of vitamin $\mathrm{C}$ in celery plant. The same trend was found in the second season.

Table 6 Effect of using different percentages decomposed of rice straw substrate on celery plants content of soluble sugar (\%), vitamin C (\%) and total yield (Kg) during 2017/2018 and 2018/2019 seasons.

\begin{tabular}{|c|c|c|c|}
\hline \multirow[t]{2}{*}{ Treatments } & Soluble sugar & Vitamin C & Yield \\
\hline & \multicolumn{3}{|l|}{ First season } \\
\hline New rice straw & $1.984 \mathrm{D}$ & $2.254 \mathrm{E}$ & $1133.3 \mathrm{D}$ \\
\hline Old rice straw 3 months & $2.969 \mathrm{~B}$ & $2.460 \mathrm{C}$ & $1275.0 \mathrm{~B}$ \\
\hline Old rice straw 6 months & $3.661 \mathrm{~A}$ & $2.548 \mathrm{~B}$ & $1376.6 \mathrm{~A}$ \\
\hline Old rice straw 9 months & $2.372 \mathrm{C}$ & $2.365 \mathrm{D}$ & $1203.8 \mathrm{C}$ \\
\hline \multirow[t]{2}{*}{ Clay soil (Control) } & $3.789 \mathrm{~A}$ & $2.656 \mathrm{~A}$ & $1381.3 \mathrm{~A}$ \\
\hline & \multicolumn{3}{|l|}{ Second season } \\
\hline New rice straw & $1.960 \mathrm{D}$ & $2.227 \mathrm{E}$ & $1130.0 \mathrm{D}$ \\
\hline Old rice straw 3 months & $2.933 \mathrm{~B}$ & $2.430 \mathrm{C}$ & $1271.7 \mathrm{~B}$ \\
\hline Old rice straw 6 months & $3.617 \mathrm{~A}$ & $2.517 \mathrm{~B}$ & $1373.0 \mathrm{~A}$ \\
\hline Old rice straw 9 months & $2.343 \mathrm{C}$ & $2.337 \mathrm{D}$ & $1201.3 \mathrm{C}$ \\
\hline Clay soil (Control) & $3.743 \mathrm{~A}$ & $2.623 \mathrm{~A}$ & $1375.3 \mathrm{~A}$ \\
\hline
\end{tabular}

\subsection{Yield}

Celery plants yield was affected positively by decomposition percentage of rice straw in both tested seasons. Table (6). Obtained that yield had slightly increased by using the clay soil and the old rice straw, 6 months treatments without any 
significant differences between them. Whereas, using the new rice straw treatment led to reduce the celery yield. The same result was noticed in the second season.

\subsection{Irrigation Water use efficiency (WUE)}

Data in Table (7) show the effect of clay soil and different decomposition percentage of rice straw substrates on irrigation water use efficiency (IWUE) of celery plants. The highest values of IWUE was recorded for plants which cultivated in old rice straw, 6 months and the clay soil, 34 and 34.1, respectively in the first season and 33.9 and 34 , respectively in the second season. In the contrary, the new rice straw substrate gave the lowest values of IWUE in both tested seasons. These results may be due to the physical characteristics of old rice straw substrate as well as clay soil which make both of them able to save sufficient available water for celery plants throw the growing season, so the plant able to grow well without any stress. On the contrary, the new rice straw and very old decomposed one have a poor characteristics and the plants which cultivated in suffering from insufficient water stress during the growing season.

Table 7 Effect of using different percentages decomposed of rice straw substrate on IWUE of celery plants during 2017/2018 and 2018/2019 seasons.

\begin{tabular}{llll}
\hline & $\begin{array}{l}\text { Total yield } \\
\text { ( Kg / GH) }\end{array}$ & $\begin{array}{l}\text { Total water } \\
\text { consumption } \\
\left(\mathbf{M}^{\mathbf{3}} / \mathbf{G H}\right)\end{array}$ & IWUE $\left(\mathbf{K g} / \mathbf{M}^{3}\right)$ \\
\cline { 2 - 4 } Treatments & Frist season & & \\
\hline New rice straw & 1360.0 & 48.6 & 28.0 \\
Old rice straw 3 months & 1530.0 & 48.6 & 31.5 \\
Old rice straw 6 months & 1651.9 & 48.6 & 34.0 \\
Old rice straw 9 months & 1444.6 & 48.6 & 29.7 \\
Clay soil (Control) & 1657.6 & 48.6 & 34.1 \\
\hline & Second season & & \\
\hline New rice straw & 1356.0 & 48.6 & 27.9 \\
Old rice straw 3 months & 1526.0 & 48.6 & 31.4 \\
Old rice straw 6 months & 1647.6 & 48.6 & 33.9 \\
Old rice straw 9 months & 1441.6 & 48.6 & 29.7 \\
Clay soil (Control) & 1650.4 & 48.6 & 34.0 \\
\hline
\end{tabular}

\section{Discussion}

Open burning of rice straw causes release of air pollutants, which contributes to enhance climate change related issues. Moreover, the burning practice was a reason of losing carbon content from crop land to the atmosphere. Moreover, burning causes a loss of nutrients and organic matter. Not only is rice straw the major organic material available to rice farmers but is considerable amount of the macronutrients, namely nitrogen, phosphorus and potassium as well as important micronutrients like sulfur and silicon are contained in the rice straw [32], [33].

Rice straw is rapidly decompose material. Its high organic matter and low organic carbon concentration were adequate for the growth [34].

The variations in substrate temperature may be due to activates of micro-organisms, which improved biodegradation of rice straw. These ability to enhance biodegradation shows potential to fasten the decomposing period [35]. In addition, [36] observed that degradation of paddy straw with fungal cultures shows an increase and higher value of cellulose activity after day 30 of degradation process. Whereas, control treatment showed the lowest activity which is expected since no inoculant were present to boost the degradation process. On other hand, during degradation period, the composition of rice straw undergoes changes to much stable fraction. The amount of lignin, hemicellulose and cellulose composition in treatment with microorganisms are much lesser than the control rice straw [35]. This is similar 
to the finding by [37], where the decrease in composition of rice straw occurrence indicated the results of breakdown or hydrolysis of complex sugar into fermentable sugars.

The general observed of increasing vegetative growth characteristics such as (plant length, plant diameter and chlorophyll reading) particularly of using decomposed rice straw might be associated with nitrogen, phosphorus and potassium levels in the media, facilitated by faster rate of decomposition of rice straw and conversion into an assimilable form for plant uptake. The results indicated in this investigation are agreement with [38], [39], [40], whom mentioned that available more water enhances nutrient availability which improves nitrogen and other macro-and micro-elements absorption as well as enhancing the production and translocation of the dry matter content from source to fruit. Also, using rice straw as a growing media help to improve the aeration of root then led to higher root zone and vegetative growth compared to cultivate in the soil [41]. However, the decrease in the growth at new rice straw might be due to the new rice straw takes more time to decompose for release of nutrients.

Other authors, reported decomposition of rice straw is responsibility of many type of microorganisms, i.e. bacteria and fungi [42], [43]. Fungi, i.e. Aspergillus, Fusarium, Trichoderma, Chyptoga Mucor sp. the main decomposer agents that can breakdown the rice straw [44]. Fungal inoculate can accelerate the decomposition of rice straw. Trichoderma sp. is the best indigenous fungi in the decomposition process of rice straw [45]. Plant growth promoting rhizobacteria (PGPR) are naturally occurring organic media bacteria that aggressively colonize plant roots and benefit plants by providing growth promotion. Inoculation of crop plants with certain strains of PGPR at an early stage of development can improve biomass production through direct effects on root and shoot growth. PGPR on vegetables have may result in multiple effects as seen in the enhancement of seed germination, stand health, plant vigor, nutrients content of plant tissues, early bloom and chlorophyll content [45], [46]. PGPR influenced the growth, yield, and increase supply with different nutrients, such as nitrogen, phosphorus, potassium, sulphur, iron and copper, produce plant hormones, enhance other beneficial bacteria or fungi [47].

The increased celery yield might be due to improved media condition which promotes faster decomposed and release of nutrients [48]. When, the decrease in yield might be due to the large volume of straw in which little water was retained, resulting in slower decomposed of the straw and release of nutrient needed for celery plants.

\section{Conclusion}

It's concluded from illustrated and discussed results that, the old rice straw, 6 months is valid and suitable substrate for growing celery plants and support it to produce its optimum crop yield. In addition, 6 months old rice straw was the best in saving water as well as nutrients depending on the best water use efficiency throughout all tested treatments in this investigation.

\section{Compliance with ethical standards}

\section{Disclosure of conflict of interest}

No conflict of interest is exist.

\section{References}

[1] Dominguez-Escriba L and M Porcar. (2010). Rice straw management: the big waste. Biofuels, Bioproducts \& Biorefining, 4(2), 154-159.

[2] El-Gammal MI and A A Shakour. (2001). Emission of pollutants from harvest and burning of rice straw in Egypt villages (North East of Nile Delta). J. Union Arab. Biol, 15, 191-206.

[3] Lemieux PM, CC Lutes and DA Santoianni. (2004). Emissions of organic air toxics from open burning: A comprehensive review. Prog. Energy Combustion. Sci, 30, 1-32.

[4] Ibrahim H Al. (2018). Bio-energy production from rice straw a review. Recent Advances in Petrochemical Science, 5(5), 1-7.

[5] Rosmiza MZ, B Amriah and ACR Rosniza. (2012). Impact of rice straw development towards agricultural environment and farmers, socio- economy in MADA region, Keddah. 
[6] El-Dewany C, F Awad and AM Zaghloul. (2018). Utilization of rice straw as a low cost natural by product in agriculture. Int. J. of Environmental Pollution \& Environmental Modelling, 1(4), 91-102.

[7] Streets DG, KF Yarber, JH Woo and GR Carmichael. (2003). Biomass burning in Asia: Annual and seasonal estimates and atmospheric emissions. Global Biogeochem. Cycles, 17, 1099-1119.

[8] Calvo AI, A Castro, V Pont, MJ Cuetos, ME Sánchez and R Fraile. (2011). Aerosol size distribution and gaseous products from the oven-controlled combustion of straw materials. Aerosol Air Qual. Res, 11, 616-629.

[9] Gadde B, S Bonnet, C Menke and S Garivait. (2009). Air pollutant emissions from rice Straw open field burning in India, Thailand and the Philippines. Environ. Pollut, 157, 1554-1558.

[10] Ito A and JE Penner. (2004). Global estimates of biomass burning emissions based on satellite imagery for the year 2000. J. Geophys. Res. 109, D14S05.

[11] Tipayarom D and NTK Oanh. (2007). Effects from open rice straw burning emission on air quality in the Bangkok Metropolitan Region. Sci. Asia, 33, 339-345.

[12] Viana M, JM Lopez, X Querol, A Alastuey, D GarciaGacio, G Blanco-Heras, P Lopez-Mahia, M PineiroIglesias, M Sanz, F Sanz, X Chi and W Maenhaut. (2008). Tracers and impact of open burning of rice straw residues on PM in Eastern Spain. Atmos. Environ, 42, 1941-1957.

[13] Hossain AMMM and K Park. (2012). Exploiting potentials from interdisciplinary perspectives with reference to global atmosphere and biomass burning management. Aerosol Air Qual. Res, 12, 123-132.

[14] Chen KS, HK Wang, YP Peng, WC Wang and CH Lai. (2008). Effects of open burning of rice straw on concentrations of atmospheric polycyclic aromatic hydrocarbons in Central Taiwan. J. Air Waste Manage. Assoc. 58, 1318-1327.

[15] Shih SI, WJ Lee, LF Lin, JY Huang, JW Su and GP Chang-Chien. (2008). Significance of biomass open burning on the levels of polychlorinated Dibenzo-pdioxins and Dibenzofurans in the Ambient Air. J. Hazard. Mater. 153, 276284.

[16] Lai CH, KS Chen and HK Wang. (2009). Influence of rice straw burning on the levels of polycyclic aromatic hydrocarbons in agricultural county of Taiwan. J. Environ. Sci. (China), 21, 1200-1207.

[17] Estrellan CR and F Iino. (2010). Toxic emissions from open burning. Chemosphere, 80, $193-207$.

[18] Bilderback TE, SL Warren, JS Owen Jr and JP Albano. (2005). Healthy substrates need physicals too. HortTechnology, 15(4), 747-751.

[19] Abdel-Satar MA. (2004). Using compacted rice straw bales in cultivated some fruits and vegetable crops. Ministry of Agriculture, Egyptian - German integrated pest management project. (In Arabic).

[20] El-Marzoky HA and MA Abdel-Sattar. (2008). Influence of growing sweet pepper in compacted rice straw bales compared with natural soil, on infection with pathogenic fungi and nematodes under greenhouse conditions. Journal of Agricultural Sciences, 16(2), 481-492.

[21] Yan C, SS Yan, TY Jia, SK Dong, CM Ma and ZP Gong. (2019). Decomposition characteristics of rice straw returned to the soil in northeast China. Nutrient Cycling in Agro ecosystems · Published online Springer Nature B.V.

[22] Malhotra SK. (2006). Celery. Handbook of herbs and spices. 317-336.

[23] Li H, Q Sun, S Zhao and W Zhang. (2000). Principles and Techniques of Plant Physiological Biochemical Experiment. Beijing, Higher Education Press.

[24] AOAC. (1990). Association of official methods of analytical chemists, official methods of analysis 15 th ed. Washington, D. C., U.S.A.

[25] Black CA. (1983). Methods of Soil Analysis.Parts 1 and 2. Amer. Soc. Agron. Jnc. Publ., Madison, Wisc., USA.

[26] Helrich K. (1990). Official methods of Analysis, 15th ed.; Association of Official Analytical Chemists (AOAC): Arlington, VA, USA.

[27] Abou-Hadid, A. F. and A. S. El-Beltagy. (1992). Water balance under plastic house conditions in Egypt. Acta Hort. 303, 61-72.

[28] Doorenbos J and WO Pruitt. (1977). Guidelines for predicting crop water requirements. In: Irrigation and Drainage Paper No. 24, FAO, Rome, 179. 
[29] Allen RG, LS Pereira, D Raes and M Smith. (1998). Crop evapotranspiration guidelines for computing crop water requirements. FAO Irrigation and drainage paper 56. Food and Agriculture Organization, Rome.

[30] Srinivas K, DM Hegde and GV Havangi. (1989). Irrigation Studies of Watermelon (Citrullus lanatus (Thunb) Mastum et Nackai). Irrig. Sci, 10, 293-301.

[31] STATSOFT. STATISTICA (data analysis software system), version 7.

[32] Singh Y and B Singh. (2001). Efficient management of primary nutrition in the rice-wheat system. In: Tataki, P. K. (ed) The rice-wheat cropping systems of South Asia: Efficient production management. pp. 23-85. Food Products Press. New York, USA.

[33] Dobermann A and TH Fairhurst. (2002). Rice straw management. Taken from better crops international, special supplement publication: Rice Production. Volume 16. Published by the Potash and Phosphate Institute of Canada.

[34] Ayinla AbA, BU Olayinka and EO Etejere. (2016). Rice straw: a valuable organic manure for soil amendment in the cultivation of groundnut (Arachis hypogaea). Environmental and Experimental Biology, 14, $205-211$.

[35] Abu Bakar NA, MH Abdul Rahman, NA Shakri, S Abu Bakar and A Abdul Hamid. (2018). Preliminary study on rice straw degradation using microbial inoculant under shake flask condition. African Journal of Biotechnology. 17(49), 1377-1382.

[36] Goyal S and S Sindhu. (2011). Composting of rice straw using different inoculate and analysis of compost quality. Microbiology Journal, 1(4), 126-138.

[37] Phutela G, N Sahni and S Sooch. (2011). Fungal degradation of paddy straw for enhancing biogas production. Indian Journal of Science and Technology, 4(6), 660-665.

[38] González-Altozano P and JR castel. (2000). Regulated deficit irrigation in 'clementina de nules' citrus trees. II: Vegetative growth. J. Hort. Sci. Biotech, 75, 388-392.

[39] Ahmed MSM, AA Farag, MAA Abdrabbo, HA Radwan, MY El-Marsafy and FA Hashem. (2015). Utilization of rice straw in tomato production under different levels of water requirements. Egypt. J. Agric. Res., 93 (5) (A), 377389.

[40] Castilla N. (1996). Drip irrigation management and water saving in protected culture. Advanced short course on Irrigation Fertilizer Management and Soilless Culture under Protected Agriculture. October 10-17, AgadirMorocco, 83-112.

[41] Sirisena DM and TP Manamendra. (1995). Isolation and characterization of cellulolytic bacteria from decomposing rice straw. J. Natn. Sci. Coun. Sri Lanka, 23 (1), 25-30.

[42] Kausar H, M Sariah, HM Saud, MZ Alam and MR Ismail. (2010). Development of compatible lignocellulolytic fungal consortium for rapid composting of rice straw. Inter Biodeter Biodegrad, 64 (7), 594-600.

[43] Nandi N, FH Rahman, NB Sinha and JN Hajra. (2000). Compatibility of lignin-degrading and cellulose decomposing fungi during decomposition of rice straw. J. Indian Soc. Sci., 48(2), 387-389.

[44] Irfan M, Q Syed, M Yousaf, M Nadeem, S Baig and SA Jafri. (2010). Studies on the Pretreatment of wheat straw for improve production of Carboxymethyl Cellulase by thermophilic Trichoderma viride - FBL1 in Solid State fermentation. Academia Arena, 2(7), 18-30.

[45] Joseph B, RR Patra and R Lawrence. (2007). Characterization of plant growth promoting rhizobacteria associated with chickpea. International Journal of Plant Production, 1(2), 141-152.

[46] Saharan BS and V Nehra. (2011). Plant Growth Promoting Rhizobacteria: A Critical Review. Life Sciences and Medicine Research. 21.

[47] Jagdev S and KP Singh. (2000). Effect of Azotobacter, FYM and fertility levels on yield, nitrogen recovery and use efficiency in spring sunflower. Haryana J. Agron, 16 (1-2), 57-60.

\section{How to cite this article}

Sadek II, Moursy FS and Ahmed Mohamed SM. (2019). Influence of using different percentages decomposed rice straw as alternative substrate on celery plants. GSC Biological and Pharmaceutical Sciences, 9(3), 116-126. 